\title{
Peranan Hukum Kepailitan Menghadang Potensi Kepailitan Dalam Industri Keuangan Syariah
}

\author{
Serlika Aprita \\ Fakultas Hukum,Universitas Muhammadiyah Palembang \\ JL.Jendral A.Yani 13 Ulu Palembang 30263 \\ Correspondence Email:5312lika@gmail.com
}

\begin{abstract}
Abstrak. Penyelesaian sengketa dalam ekonomi syariah dapat ditempuh melalui jalur litigasi. Jika mengacu pada Pasal 2 ayat (1) UU No. 37 Tahun 2004 tentang Kepailitan dan Penundaan Kewajiban Angsuran, dinyatakan bahwa seorang debitur yang mempunyai sekurang-kurangnya dua orang pemberi pinjaman dan tidak melunasi paling sedikit satu kewajiban yang telah timbul dan dapat ditagih, dinyatakan pailit berdasarkan pilihan pengadilan., baik atas ajakan sendiri atau sejalan dengan sekurangkurangnya satu pemegang utang. lebih banyak penyewa. Jika perkara yang dimaksud adalah perkara likuidasi keuangan syariah, pengadilan yang dimaksud dalam Undang-Undang ini adalah Pengadilan Tinggi. Strategi pemeriksaan yang digunakan adalah standarisasi eksplorasi yang halal. Namun, seiring dengan berkembangnya organisasi-organisasi standar dan organisasi-organisasi yang bergerak sebagai lembaga moneter, baik bank maupun non-bank, otoritas publik harus bereaksi dengan memberikan pengadilan khusus untuk menyelesaikan kasus-kasus bisnis yang dilakukan oleh organisasi-organisasi Islam. Dengan cara ini, penting bahwa Pengadilan Bisnis yang berada dalam iklim Pengadilan Ketat dibuat untuk memenuhi kepastian hukum, nilai dan komponen ekuitas untuk elemen sah perusahaan yang mempertahankan bisnisnya dengan standar syariah.
\end{abstract}

Kata Kunci: lembaga penyelesaian sengketa, ekonomi syariah, kepailitan syariah.

Abstract. Dispute resolution in sharia economics can be pursued through litigation. If referring to Article 2 passage (1) of Law No. 37 of 2004 concerning Liquidation and Delay of Obligation Installment Commitments, it is expressed that a debt holder who has at least two lenders and doesn't pay off somewhere around one obligation that is expected and can be If the case alluded to is a sharia monetary chapter 11 case, the court alluded to in this Law is the Strict Court. The exploration technique utilized is standardizing lawful examination. However, along with the growth of ordinary companies and companies that act as financial institutions, both banks and non-banks, the government should respond by providing a special court to resolve commercial cases committed by Islamic companies. Thus, it is necessary that the Commercial Court within the Religious Courts be established in order to fulfill legal certainty, usefulness and elements of justice for corporate legal entities that run their business with sharia principles.

Keywords: dispute resolution institutions, sharia economics, sharia bankruptcy.

\section{PENDAHULUAN}

Industri keuangan syariah potensi kemajuannya sangat besar, dibandingkan dengan negara lain, Indonesia masih sangat jauh tertinggal. Industri keuangan syariah juga mengalami tantangan yang besar sehubungan dengan adanya covid-19, sehingga pertumbuhan ekonomi menjadi sangat tidak stabil. Dimana ada kenaikan perkara dalam jummlah perkara di Pengadilan Niaga. Dimana salah satu penyebabnya adalah kesulitan ekonomi akibat covid-19. Dalam dunia bisnis, pasang surut keuangan suatu hal yang lazim. Termasuk dalam industri keuangan dan sektor bisnis syariah, tidak jarang kesulitan keuangan menyebabkan debitor dipailitkan, bahkan tidak jarang juga menimpa kreditor karena sebab tertentu. Kepailitan dalam konteks hukum dapat dimaknai sebagai ketidakmampuan peminjam untuk memenuhi komitmennya kepada pemberi pinjaman pada waktu yang telah ditentukan sebelumnya. Dengan asumsi ada ketidakberdayaan untuk membayar kewajiban, ${ }^{1}$ salah satu pengaturan hukum yang dapat diambil oleh kedua peminjam dan pemberi pinjaman adalah melalui undang-undang pasal 11 dengan mengajukan permohonan penundaan komitmen angsuran kewajiban (PKPU) atau kepailitan ke Pengadilan Niaga. Namun bagi industri keuangan atau bisnis syariah, mekanisme PKPU dan Kepailitan di Pengadilan Niaga dirasakan tidak dirasakan sesuai dengan prinsipprinsip syariah, sehingga menurut UU No.3 Tahun 2016 serta Putusan Mahkamah Konstitusi Tahun 2012 menjadi ranah absolut dari peradilah agama atau mahkamah Syariah. ${ }^{2}$

Upaya restrukturisasi industri keuangan syariah menghadapi Covid-19 dimana untuk industri keuangan syariah juga terdampak. Untuk itu OJK melalui POJK No.11/POJK.03/2020 telah memberikan pelonggaran terhadap bisnis moneter, termasuk syariah, di mana telah memberikan kemudahan langkah-langkah pembangunan kembali dan

${ }^{1}$ Trisadini Prasastinah Usanti dan Nurwahjuni, Model Penyelesaian Kredit Bermasalah, (Surabaya: Revka Pertra Media, 2014), hlm. 100.

${ }^{2}$ Any Nugroho. Hukum Perbankan Syariah. (Yogyakarta:Aswaja Pressindo,2015),hlm.12. 
penjadwalan ulang untuk klien yang terkena dampak virus Corona. ${ }^{3}$ Khusus untuk UMKM atau yang memiliki pembiayaan di bawah Rp 10 miliar, khususnya untuk industri perjalanan, transportasi, penginapan, pertukaran, penanganan dan pertambangan. Berkenaan dengan sistem Insolvensi dan PKPU syariah, khususnya masalah keuangan syariah telah menjadi kewenangan Pengadilan Tinggi. Kemana saja seharusnya dirumuskan satu regulasi tentang kepailitan syariah berupa UU atau dimasukan dalam perubahan UU Kepailitan yang ada sekarang, khususnya mengenai kepailitan syariah yang sudah seharusnya untuk diakomodir, termasuk dalam mekanisme penyelesaiannya yang harus menjadi bagian dari sengketa ekonomi syariah. Banyaknya perkara kepailitan dalam lembaga keunagan syariah yang ditangani oleh Pengadilan Niaga yang memang tidak sesuai dengan prinsip syariah, untuk itu ia mendorong agar kepailitan syariah ditangani oleh Pengadilan Agama.

Terdapat perebutan standar antara Undang-Undang Nomor 37 Tahun 2004 tentang Likuidasi dan Penundaan Komitmen Angsuran Kewajiban dengan Pedoman Pengadilan Tinggi 2/2008 tentang Pengumpulan Undang-Undang Moneter Syariah (KHES) dan Perma Nomor 14 Tahun 2016 tentang Tata Cara Pelunasan Perkara Keuangan Syariah, mendorong kepailitan di sektor ekonomi syariah ke Pengadilan Agama. ${ }^{4}$ Perlu adanya harmonisasi dan kamarisasi mengenai kepailitan dan PKPU di sektor bisnis syariah. Untuk itu diusulkan perlu adanya fatwa DSN MUI terkait mekanisme kepailitan syariah agar menjadi pedoman bagi industri keuangan syariah. Selain itu juga mendorong Mahkamah Agung khususnya kamar agama untuk melakukan perubahan Perma mengenai ekonomi syariah dengan memasukan kompetensi penanganan kepailitan di bidang bisnis syariah, walaupun terjadi resistensi, perlu terus didorong terwujudnya mekanisme kepailitan yang sesuai dengan prinsip-prinsip syariah. ${ }^{5}$

Dalam dunia bisnis, pasang surut keuangan suatu hal yang lazim. Termasuk dalam industri keuangan dan sektor bisnis syariah, tak jarang kesulitan keuangan menyebabkan debitur dipailitkan, bahkan tak jarang juga menimpa kreditor karena sebab tertentu. Kepailitan dalam konteks hukum dapat dimaknai sebagai ketidakberdayaan pemegang rekening (pemegang utang) untuk memenuhi komitmennya kepada penyewa pada waktu yang telah ditentukan sebelumnya. Dengan asumsi ada ketidakberdayaan untuk membayar kewajiban, salah satu pengaturan yang sah yang dapat ditempuh oleh dua pemegang utang dan pemberi pinjaman adalah melalui undang-undang likuidasi dengan mengajukan permohonan penangguhan komitmen angsuran kewajiban (PKPU) atau kepailitan ke Pengadilan Bisnis. Namun bagi industri keuangan atau bisnis yang bergerak dengan prinsip syariah, mekanisme PKPU dan kepailitan di Pengadilan Niaga dirasa tidak sesuai dengan prinsip-prinsip syariah. Sehingga menurut UU No 3 Tahun 2016 serta Putusan Mahkamah Konstitusi tahun 2012, menjadi ranah kompetensi absolut dari Peradilan Agama atau Mahkamah Syariah. ${ }^{6}$

Upaya rekstrukturisasi industri keuangan syariah menghadapi Covid-19 dimana industri keuangan syariah juga terdampak. Untuk itu OJK melalui POJK No. 11/POJK.03/2020 telah memberikan kelonggaran terhadap bisnis moneter, mengingat syariah telah memberikan kemudahan dalam membangun kembali dan menjadwal ulang langkahlangkah untuk klien yang terkena dampak virus Corona. Khusus untuk UMKM atau yang memiliki pembiayaan di bawah Rp 10 miliar, terutama untuk industri perjalanan, transportasi, penginapan, pertukaran, persiapan dan area pertambangan. Mengenai sistem PKPU dan Bab 11 dalam industri bisnis syariah, tidak diragukan lagi harus ada PKPU dan instrumen penyelesaian kepailitan syariah, terutama karena perdebatan keuangan syariah telah berubah menjadi kewenangan Pengadilan, pedoman likuidasi syariah harus dianggap sebagai undang-undang atau dikenang untuk revisi Undang-Undang Likuidasi saat ini. Jumlah kasus likuidasi di yayasan moneter Islam yang ditangani oleh Business Court yang memang tidak sesuai dengan prinsip syariah.

Dalam Undang-Undang Nomor 37 Tahun 2004 tentang Likuidasi dan Penundaan Kewajiban Komitmen Bagian (UUK-PKPU), yang dimaksud oleh pengadilan adalah bahwa yayasan yang memenuhi kebutuhan untuk menyelesaikan pasal 11 perkara dinyatakan dalam Pasal 1 ayat (7) khususnya Pengadilan Bisnis yang berada di lingkungan pengadilan secara umum. . Dalam pasal lain, khususnya Pasal 300 ayat (1): "Pengadilan sebagaimana dimaksud dalam Undang-Undang ini, sebagaimana halnya memeriksa dan memilih permohonan penegasan Pasal 11 dan Penundaan Tanggung Jawab Bagian, juga didukung untuk memeriksa dan memilih kasus-kasus yang diubah. dalam bidang usaha yang isiannya dilengkapi demi hukum". ${ }^{7}$ Dengan mempertimbangkan pasal-pasal ini, secara spekulatif, disimpulkan bahwa kasus-kasus kepailitan dan kasus-kasus berbeda yang muncul dari pasal 11 atau pertukaran yang berbeda berada di bawah lingkungan Pengadilan Bisnis secara langsung. Padahal, sekali lagi, yang

${ }^{3}$ Ashinta Sekar Bidari, Reky Nurviana, "Stimulus Ekonomi Sektor Perbankan Dalam Menghadapi Pandemi Coronavirus Disease 2019 Di Indonesia”, Jurnal Ilmu Hukum, Vol. 4 No. 1, Maret 2020, hlm. 298.

${ }^{4}$ Sutan Remy Sjahdeini,. Sejarah, Asas, dan Teori Hukum Kepailitan: Memahami Undang-Undang No. 37 Tahun 2004 Tentang Kepailitan dan Penundaan Kewajiban Pembayaran. (Jakarta: Kencana,2015),hlm.77. hlm.33.

${ }^{5}$ Ahmad Mujahidin,. Prosedur Penyelesaian Sengketa Ekonomi Syariah di Indonesia, (Jakarta: Ghalia Indonesia,2010),

${ }^{6}$ Amran Suadi, Penyelesaian Sengketa Ekonomi Syariah Teori dan Ekonomi, (Jakarta : Penerbit Kencana, 2017$)$, hlm. 329.

${ }^{7}$ Sutan Remy Sjahdeini,. Sejarah, Asas, dan Teori Hukum Kepailitan: Memahami Undang-Undang No. 37 Tahun 2004 Tentang Kepailitan dan Penundaan Kewajiban Pembayaran.( Jakarta: Kencana,2015),hlm.76. 
disempurnakan oleh perkumpulan-perkumpulan yang menggunakan prinsip syariah adalah pengembangan "Ekonomi Syariah". Dan semua kasus yang muncul dari praktik terkait uang syariah secara spekulatif berada di bawah lingkup Pengadilan Parah. Hal ini dapat ditemukan dalam Pasal 49 UU No. 3 Tahun 2006 tentang Pemerataan yang Berat. Mengingat pertanyaan antara dua asosiasi yang sah, ada kejanggalan yang konsisten interminis dalam kekuasaan segera untuk menyelesaikan likuidasi asosiasi syariah.

Peningkatan struktur moneter Islam saat ini semakin kuat dan inovatif. Pasalnya, tidak hanya banyak negara yang berlomba-lomba untuk fokus pada masalah keuangan syariah, tetapi juga semakin beragamnya instrumen keuangan syariah dalam organisasi keuangan syariah. Mulai dari perbankan syariah, asuransi syariah, dan sektor usaha permodalan syariah. Demonstrasi sudut pandang uang Islam yang memenuhi berbagai distrik di planet ini, secara bertahap membawa kemajuan ke instrumen yang sah juga. Dimana pada awalnya tidak ada instrumen hukum moneter Islam yang substansial, saat ini telah dibuat hal-hal unik dalam hukum moneter Islam.

Sesuatu yang secara jujur dimunculkan oleh kegiatan perspektif moneter syariah di Indonesia adalah terbitnya UU No. 21 Tahun 2008 tentang Perbankan Syariah. Sejak berdirinya bank syariah di Indonesia pada tahun 1992, para ahli publik telah mengesahkan undang-undang dan peraturan yang terkait dengan Perbankan Syariah. Saat ini, Perbankan Syariah diatur dalam UU No. 21 Tahun 2008 tentang Perbankan Syariah. Sebagaimana dinyatakan dalam undang-undang tersebut, kami memandang bahwa di Indonesia terdapat dua struktur moneter, yaitu sistem normal dan sistem syariah. Hukum mengoordinasikan dari atas ke bawah dengan alasan yang sebenarnya, misalnya, jenis asosiasi yang dapat dijalankan dan dijalankan oleh bank syariah. Dengan kemajuan organisasi terkait uang Islam di Indonesia, peluang olok-olok antara lembaga keuangan Islam dan pelanggan mereka akan jauh lebih menonjol. ${ }^{8}$

\section{METODE}

Untuk menemukan jawaban atas permasalahan di atas, tulisan ini menggunakan standarisasi pemeriksaan yang sah. Standarisasi pemeriksaan yang sah adalah eksplorasi yang sah atas pedoman, standar, dan standar yang sah, termasuk konvensi yang sah yang membuat dan berkaitan dengan subjek eksplorasi. ${ }^{9}$ Menurut Soejono Soekonto, pengaturan pemeriksaan yang sah bertujuan untuk penelitian yang mengacu pada standar hukum, sistematika hukum, sinkronisasi hukum dan pedoman, dekat dengan hukum, dan sejarah yang sah. ${ }^{10}$ Bahan hukum yang digunakan dalam audit ini dipisahkan menjadi tiga bahan yang sah yaitu fundamental, discretionary, dan tersier. Materi legitimasi yang mendasar adalah UU no. 37 Tahun 2004 tentang Bagian 11, UU No. 3 Tahun 2006 tentang Pemerataan Berat, Putusan Pengadilan Nomor 93/PUU/X/2012 dan PERMA Nomor 2 Tahun 2008 tentang KHES. Perlengkapan opsional yang sah umumnya adalah referensi yang sah yang dikecualikan dari arsip negara yang sebenarnya seperti buku, eksposisi, proposal, dll yang memenuhi subjek ujian. Selain itu, untuk menyelesaikan dua bahan yang sah, diperlukan beberapa istilah yang sah dan tidak dikenal yang diingat untuk beberapa kata referensi, buku referensi dan kesimpulan yang memenuhi syarat tentang tema penelitian sebagai fitur bahan hukum tersier. Metodologi yang digunakan dalam eksplorasi ini adalah rule approach (metodologi yang sah) dan metodologi yang dihitung (the idea approach). Metodologi hukum adalah untuk berkonsentrasi secara preskriptif tentang standar tindakan hukum, sedangkan pendekatan ide adalah untuk membangun ide total pemeriksaan ini baik dengan menyempurnakan ide-ide yang ada atau tidak ada. Pemeriksaan khusus yang digunakan adalah sinkronisasi dan harmonisasi dengan menggunakan hipotesis kekuasaan dan kaidah lex terlatih profesional.

\section{HASIL DAN PEMBAHASAN}

\section{Kedudukan Pengadilan Niaga dan Kewenangannya dalam Menyelesaikan Perkara Kepailitan}

Pailit adalah suatu kondisi di mana peminjam tidak dapat melakukan angsuran atas kewajibannya kepada banknya. Kondisi tidak mampu membayar biasanya karena kesengsaraan moneter (Monetary Trouble). ${ }^{11}$ Namun demikian, pailitnya suatu bank tidak sesederhana pailitnya suatu organisasi biasa sebagaimana dinyatakan dalam Pasal 2 ayat (1) UU No. 37 Tahun 2004 tentang Likuidasi dan Penundaan Ikatan Angsuran Kewajiban, dengan lebih spesifik: "Peminjam yang mempunyai sekurang-kurangnya dua orang pemberi pinjaman dan tidak melunasi paling sedikit satu kewajiban yang telah timbul dan dapat ditagih, dinyatakan pailit oleh pengadilan. pilihan, baik atas permintaan mereka sendiri atau sejalan dengan setidaknya satu pemberi pinjaman". Kemudian, pada saat itu yang menjadi persoalan adalah salah satu ormas Islam dianggap tidak mampu membayar kewajibannya, lalu pada saat itu harus diajukan permohonan likuidasi? Pengadilan Bisnis bukanlah perluasan ke pengadilan lain, Pengadilan Bisnis penting untuk atau berada di dalam iklim Pengadilan Keseluruhan. Hal ini dapat dibayangkan berdasarkan Pasal 8 UU

8Mardani, Hukum Ekonomi Syariah di Indonesia (Bandung: PT. Refika Aditama, 2011), hlm. 97.

${ }^{9}$ Soerjono Soekanto \& Sri Mamudji, Penelitian Hukum Normatif (Suatu Tinjauan Singkat), ( Jakarta : Rajawali Pers, 2001), hlm,23.

${ }^{10}$ Soerjono Soekanto, Pengantar Penelitian Hukum, (Jakarta: UI Press, 2007), hlm. 51.

${ }^{11}$ Serlika Aprita, Hukum Kepailitan dan Penundaan Kewajiban Pembayaran Utang:Perspektif Teori, (Malang:Setara Press,2018).hlm.45. 
No. 2 Tahun 1986 tentang Peradilan Umum, khususnya, "Dalam peradilan biasa dapat dibuat spesialisasi-spesialisasi yang diminta oleh undang-undang". Selain itu, dalam penjelasan pasal tersebut, "spesialisasi" adalah adanya detasemen/spesialisasi dalam lingkungan hukum secara umum, misalnya Peradilan Wilayah, Peradilan Remaja, Peradilan Keuangan", dan salah satunya adalah Peradilan Wilayah. Pembentukan pengadilan bisnis sebagai asosiasi yang menangani kasus pasal 11 bergantung pada pertimbangan kecepatan dan keluasan.Pasal 11 Perkara dalam UUKPKPU ditentukan oleh jangka waktu penyelesaian di tingkat pengadilan bisnis, dan penyembuhan yang sah yang dapat diambil oleh pihak yang mendokumentasikan perbedaan pendapat secara langsung di tingkat kasasi ke Pengadilan Tinggi tanpa ada rayuan kepada Pengadilan Tinggi. Pengadilan. Oleh karena itu, kasus likuidasi akan diselesaikan lebih cepat daripada kasus normal di pengadilan daerah. Jadi secara normatif kewenangan langsung pengadilan bisnis adalah untuk menganalisis, mengadili dan memilih kasus-kasus permohonan likuidasi dan penangguhan komitmen angsuran kewajiban (PKPU). Ini juga diklarifikasi dalam Pasal 300 ayat (1) UUK-PKPU, bahwa permohonan pailit dan verbalisasi PKPU dianalisis dan dipilih oleh visioner bisnis. Dengan rencana pasal ini, mungkin memberikan pemahaman bahwa setiap instansi likuidasi dan PKPU yang diarsipkan setelah pengukuhan UU No. 37 Tahun 2004 harus diajukan ke pengadilan bisnis. Selain tindakan yang ditentukan dalam UUK-PKPU, kewenangan langsung pengadilan bisnis atas kasus kepailitan juga diperkuat oleh undang-undang. Putusan Perdebatan Tinggi Sah No.013PK/N/1999 tanggal 2 Agustus 1999 tentang gambaran penilaian sahnya kata likuidasi antara PT Putra Putri Fortuna dan rekan-rekannya, sebagai kemungkinan PK terhadap PT Persatuan Hayati Indonesia (PT Enindo ) dan mitra, sebagai diidentifikasi dengan apakah badan Mediasi dapat menyelesaikan kasus kepailitan.

Dalam pertimbangannya yang sah, para ajudikator menilai bahwa "walaupun Diskresi merupakan tambahan hukum yang dibawa ke dunia dari kondisi mediasi. Statuta telah merasakan dampak yang sah yang memberikan Asersi kekuatan untuk menyelesaikan kasus-kasus yang muncul. dari suatu pengertian, berdasarkan pedoman Pacta Sunt Servenda (1338 Common Code).Meskipun demikian, dalam pertimbangan-pertimbangan tambahan yang sah, hakim menyatakan bahwa, bagaimanapun, ahli langsung dalam situasinya sebagai tambahan hukum tidak dapat menggantikan otoritas pengadilan bisnis (exctra standar) yang secara tegas disetujui untuk melihat dan mengintervensi penyelesaian atau likuidasi kewajiban. UU-PKPU terbaru juga mengoordinasikan penyelesaian pertanyaan pasal 11 tentang persetujuan dengan proklamasi opsional, untuk lebih eksplisit "Pengadilan masih mendukung untuk melihat dan menyelesaikan tuntutan penegasan pasal 11 dari majelis yang mengendalikannya. pernyataan perjanjian, sepanjang komitmen yang menjadi alasan di balik permohonan likuidasi itu telah mendukung jalannya perbuatan sebagaimana dimaksud dalam Pasal 2 ayat (1) Undang-undang ini." Terlepas dari penilaian tersebut, dapat pula dipertimbangkan untuk menentukan konflik antara pengadilan bisnis atau badan mediasi, khususnya melalui aturan dan aturan otorisasi yang sah di Indonesia. menyajikan enam prinsip Salah satu norma tersebut adalah bahwa undangundang yang dibuat oleh organisasi yang lebih tinggi memiliki kedudukan dan kedudukan yang lebih besar. Penyelesaian olok-olok likuidasi yang direkomendasikan oleh hukum adalah badan pengadilan. Aturan UUK-PKPU tentang pengadilan bisnis dikaitkan dengan bagian V "pedoman yang unik" mulai dari Pasal 299-302 dan karenanya menyebar di berbagai pasal dan pemberitahuan itu cukup dengan "pengadilan", hal ini dengan mengacu pada pengaturan Pasal 1 angka (7) yang dimaksud dengan pengadilan adalah pengadilan bisnis. Sampai dengan pemberitahuan lebih lanjut, alasan permintaan melalui kantor media I biasanya muncul dalam pengaturan yang dibuat antara orang yang berkewajiban dan bank, sehingga berdasarkan aturan ini, mengakui kekuatan yang diberikan oleh undang-undang memiliki status yang lebih tinggi daripada kontrak yang diselesaikan oleh dua pertemuan interogasi. Oleh karena itu, sudah sepatutnya penyelesaian sengketa pasal 11 diselesaikan di pengadilan bisnis. Mengingat klarifikasi ini, tampaknya memberikan jaminan yang sah bahwa kasus-kasus kepailitan adalah wewenang langsung dari Pengadilan Bisnis. Dengan tujuan bahwa pengadilan yang berbeda dan badan tujuan debat yang tidak sesuai secara mengejutkan tidak memenuhi syarat untuk menyelesaikan kasus likuidasi. 


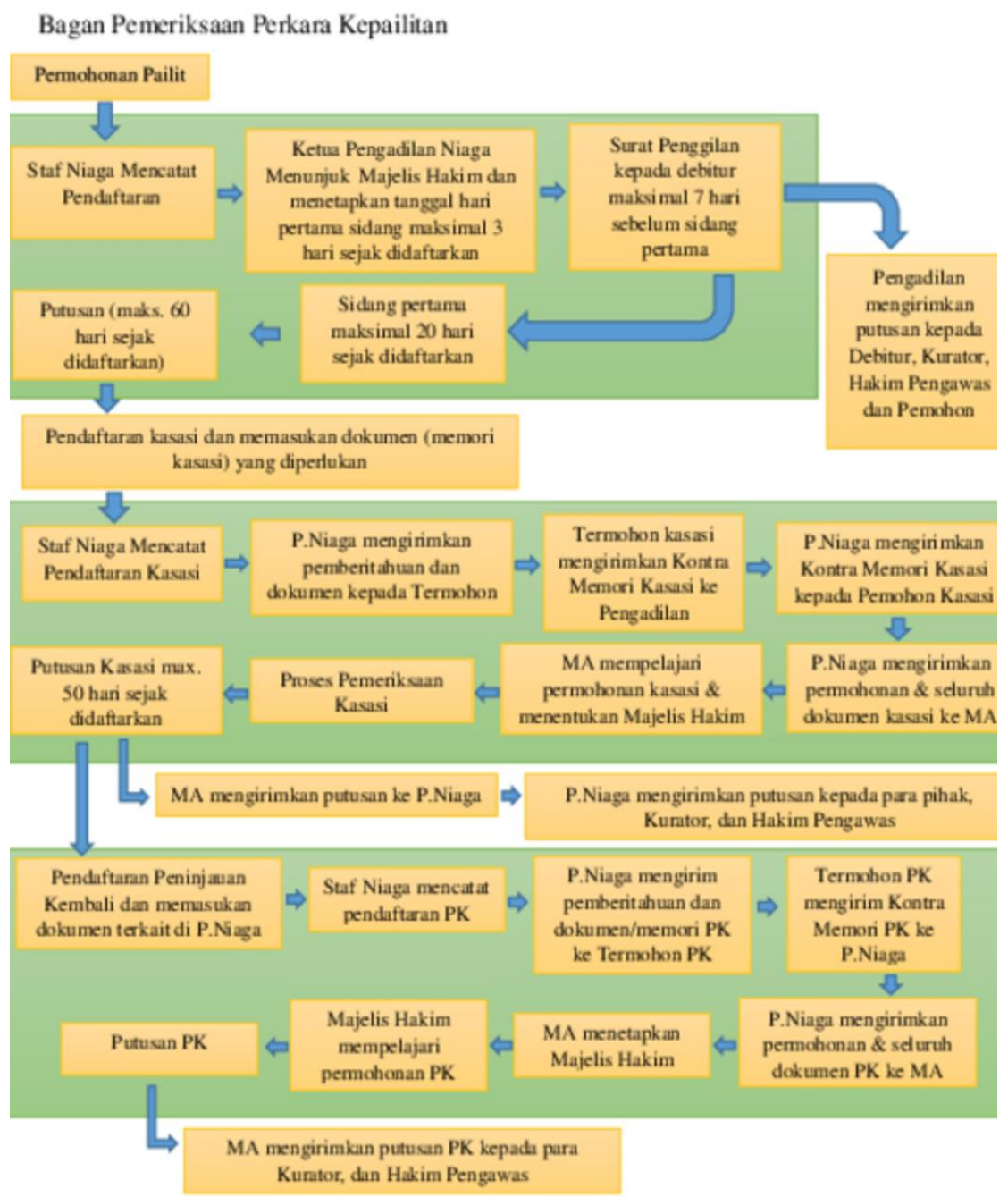

\section{Latar Belakang Dualisme Kewenangan Mengadili Antara Pengadilan Niaga Dan Pengadilan Agama Dalam Perkara Kepailitan Dan PKPU Pada Lembaga Keuangan Syariah}

Mengenai pemaksaan yang terjadi antara Pengadilan Bisnis dan Pengadilan Tinggi dalam memeriksa dan menengahi kasus likuidasi dan PKPU di yayasan moneter Islam, itu benar-benar terletak pada ruang pencampuran wilayah hukum adat (umum) ke wilayah publik yang mengejutkan. Undang-undang yang menggunakan prinsipprinsip hukum moneter syariah, membawa kemajuan pemanfaatan. hukum adat ke ruang hukum keuangan syariah merupakan bagian dari kelemahan halal. Selama ini Pasal 11 berlaku secara lengkap, khususnya bagi semua orang atau perkumpulan yang akan dilikuidasi sehingga tidak mengetahui apakah pasal 11 itu normal atau tergabung dalam pengertian keuangan syariah dalam pengaturannya. Sementara itu, dalam perspektif hukum terkait uang syariah itu sendiri, likuidasi yang terjadi pada badan-badan terkait uang syariah atau orang-orang yang melakukan pengaturan moneter syariah dipandang sebagai bagian dari semacam "penyelidikan" yang pada umumnya dirasakan oleh Pengadilan. pasal 49 huruf (I) UU. Nomor 3 Tahun 2006 tentang Pemerataan yang Berat. Mengutip penilaian M. Natsir Asnawi bahwa selama kerumitan atau kerumitan itu tidak dijelaskan, makna olok-olok harus tetap pada makna umumnya, khususnya mencakup berbagai pertanyaan yang telah dan mungkin terjadi di bidang uang Islam. ${ }^{12}$

Tentu saja, percampuran kekuatan juga terjadi karena perluasan kemampuan Mahkamah Agung ke dalam ranah hukum publik menurut hukum keuangan syariah. Prinsip-prinsip orang Islam sampai sekarang tidak dipandang sebagai individu Muslim, tetapi telah digambarkan sebagai orang non-Muslim atau substansi hukum biasa yang dengan sengaja menyerah dan mengikat secara sah rencana permainan yang tunduk pada pengaturan keuangan syariah. Peningkatan kemampuan hukum Dalam ranah hukum moneter syariah telah menyusup ke dalam batas wilayah hukum adat secara keseluruhan yang telah menjadi panutan sejati bagi masyarakat Indonesia sehingga memungkinkan untuk mengkoordinir wilayah hukum adat secara menyeluruh dengan hukum terkait uang syariah semakin jelas. 
Benturan norma antara Undang-Undang Nomor 37 Tahun 2004 tentang Likuidasi dan PKPU dengan Pedoman Pengadilan Tinggi Nomor 2 Tahun 2008 tentang Macam-Macam Hukum Uang Syariah (KHES) dan Perma Nomor 14 Tahun 2016 tentang Kerangka Pembahasan Ekyar Pelunasan. UU No. 37 Tahun 2004 membawa pembahasan likuidasi ke Pengadilan Niaga sedangkan Perma No. 2 Tahun 2008 dan Perma No. 14 Tahun 2016 memberi kuasa kepailitan di bidang moneter syariah ke Pengadilan Tinggi untuk melakukan harmonisasi dan roomisasi terhadap pasal 11 dan PKPU di kawasan bisnis syariah. Oleh karena itu, penting untuk memiliki fatwa DSN MUI yang diidentikkan dengan sistem kepailitan syariah sehingga menjadi aturan bagi industri uang syariah. Selain itu, juga memberikan wewenang kepada Pengadilan Tinggi, khususnya kamar-kamar yang ketat untuk melakukan perubahan Perma mengenai masalah keuangan syariah dengan memasukkan kemampuan mengurus kepailitan di bidang bisnis syariah. Meskipun ada pertentangan, kami akan terus memperkuat landasan instrumen pasal 11 yang sesuai dengan standar syariah. Sampai saat ini, debat di pengadilan membutuhkan banyak waktu, uang, dan energi, meskipun standarnya cepat, mendasar, dan biayanya minimal. Bagaimanapun, yang terjadi memang sering tidak sesuai dengan pedoman. Demikian pula dalam penyelesaian soal-soal di bidang keuangan dan bisnis syariah. ${ }^{13}$ Dengan asumsi Anda perlu mengambil langkah yang sah di Pengadilan, Lembaga Bantuan Keuangan Syariah (LJKS) atau klien harus merenungkan kompleksitas yang terjadi, juga bahwa tidak semua hakim yang ketat memiliki pemahaman yang sama tentang hukum keuangan syariah, yang sejujurnya adalah sebagai namun tidak bersahabat. Untuk mengatasi hal ini, penting untuk menentukan target penyelidikan keputusan di bidang uang Islam yang merupakan substansi yang sah dan dirasakan oleh para ahli. Sehingga kualitasnya dapat berubah menjadi tujuan soal pilihan yang sederhana, cepat dan mendasar serta memiliki daya paksa bagi LJKS.

Kehadiran BASYARNAS telah dirasakan dalam pedoman hukum seperti UU No. 30 Tahun 1999, Pedoman Pengadilan Tinggi dan selanjutnya Fatwa DSN MUI, namun diakui belum cukup maksimal untuk sampai pada pertanyaan moneter syariah di distrik. Hal lain yang menjadi persoalan adalah pengaturan yang tidak tertib di antara majelis-majelis, yang dalam perjanjian tersebut sebenarnya menetapkan dua alternatif penyelesaian yang sah, yaitu BASYARNAS dan Pengadilan Tinggi. Soal-soal di Pengadilan Ketat menghabiskan sebagian besar hari dalam waktu yang cukup lama bahkan ada yang membutuhkan waktu satu tahun untuk menyelesaikannya. Ini menunjukkan bahwa interogasi di pengadilan tidak kuat. Sementara itu, jika Anda mengambil kursus BASYARNAS, tidak semua kabupaten memiliki BASYARNAS, ini juga menjadi masalah. Pada tahun 2011, MES telah memulai Badan Syafaat Moneter Syariah (BAMES), lengkap dengan semua tolnya. Namun, setelah Beberapa waktu kehadiran BAMES juga tidak dapat hadir karena komponen yang berbeda. Ketua Bidang Dukungan MES menyampaikan bahwa penataan Slip merupakan hal mendesak yang harus segera ditindaklanjuti. Lagi-lagi, Thalis mengungkapkan bahwa akan lucu jika tidak ada LAPS yang secara eksplisit mengatur perdebatan moneter dan bisnis syariah. Bahkan, baru 6 LAPS yang terdaftar di OJK yang semuanya non syariah, antara lain BMAI untuk proteksi, BAPMI untuk bidang usaha permodalan, LAPSPI untuk perbankan, BAMPPI untuk penjaminan dan BMPPI untuk toko barang bekas dan lembaga pembiayaan. Disampaikan Pengurus KOHEBSI, kehadiran Omissions akan menjadi ajang silaturahmi bagi LAPS bagi industri administrasi moneter syariah, baik perbankan syariah, perlindungan syariah, pembiayaan syariah, termasuk fintech syariah. Menurut dia, tanda langkah penyelesaian dalam Slip adalah syafaat oleh Arbiter Syariah yang telah ditegaskan oleh Pengadilan Tinggi dan Ajudikator dan Mediator Syariah yang dijamin oleh Pengadilan Tinggi yang nantinya dapat dipulihkan dari BASYARNAS. Oleh karena itu, ia berkeyakinan bahwa semua hubungan bantuan moneter syariah di bawah OJK, harus bersatu dan bersinergi untuk pengakuan Pelanggaran ini. Dari hasil pemeriksaan diketahui bahwa alasan perkara tersebut saat ini sedang ditangani oleh Pengadilan Bisnis karena adanya benturan baku antara UU Kepailitan dan PERMA tentang KHES yang sampai saat ini belum terselesaikan. ., terdapat kekosongan legitimasi sejauh likuidasi yang bertumpu pada akad syariah dan adanya surat KMA No. 32/SK/IV/2006 tentang aturan pelaksanaan buku II. Hasil nyata jika kasus tersebut ditangani oleh Pengadilan Bisnis adalah ketidaknyamanan substansi hukum terkait uang Islam ke dalam hukum moneter umum, perdebatan antara tujuan dan alamat yang mengikat secara hukum dan pemikiran angsuran kasus yang menekankan pada norma-norma bisnis dan pengaturan bisnis alih-alih nilai yang murah hati. Mengingat kekuatan spekulasi dan pedoman master materi lex, dianggap bahwa pasal 11 kasus dan PKPU mengandalkan kontrak syariah adalah kapasitas langsung dari Pengadilan.

${ }^{13}$ Yudha Indrapraja, Kegagalan Hukum di Indonesia Dalam Menciptakan Kepastian Hukum Terkait Sengketa Kepailitan Perbankan Syariah, Jurnal As-Syariah, Vol 16, (2014), h. 233. 


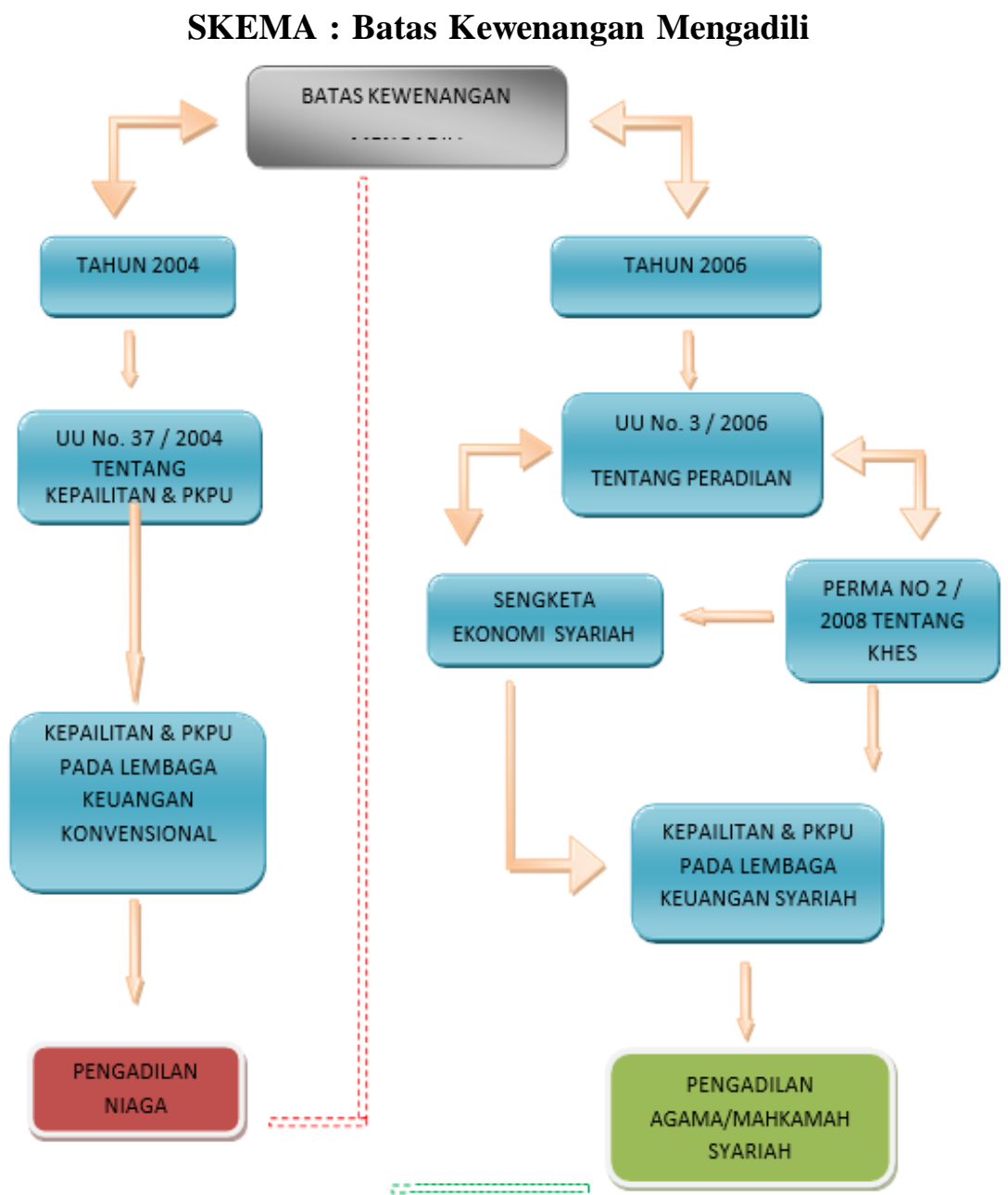

Garis Merah Putus-putus adalah batas kewenangan Pengadilan Niaga.

Garis Hijau putus-putus adalah batas kewenangan Pengadilan Agama/Mahkamah Syariah.

\section{Adanya Kondisi "Legal Loophole"tentang Hukum Kepailitan Syariah}

Sejak disahkannya Undang-Undang Nomor 3 Tahun 2006 tentang Hukum Berat, aturan Syariah Bagian 11 sampai saat ini belum ada. Faktor super yang dapat dibayangkan adalah bahwa situasi Pasal 11 dan PKPU akan menjadi kasus yang jarang naik ke atas dan tidak sebanyak kasus umum yang luas sehingga para ahli publik untuk keadaan sekarang tidak melatihnya. . DPR secara andal mengakui keberadaan UU tersebut. Anehnya, dalam pasal 49 huruf (I) mengenai segmen penjelasan "aspek keuangan syariah" hanya menitikberatkan pada poin (k) saja dan tidak menolak indikasi likuidasi syariah sebagai salah satu komponen pembahasan terkait uang syariah.

Menurut Amran Suadi (Pengawas Mahkamah Agung) ketika kondisi pembicaraan Hukum Mahkamah Agung sekitar saat itu, pada saat itu, kaki tangan dan ahli Pengadilan Parah sengaja menghindari tanda pasal 11 yang bergantung pada kontrak syariah sebagai komponen syariah. Dalam diskusi terkait uang, ini adalah upaya politik yang murni dengan tujuan memposisikan hukum moneter Islam ke dalam wilayah hukum publik tidak terlihat serius dan radikal dan membutuhkan siklus yang benar-benar berkembang untuk dirasakan oleh masyarakat secara keseluruhan. Bagian dari titik sekitar kemudian adalah untuk menghindari pengaruh Pengadilan Parah dalam menangani diskusi keuangan syariah sehingga tidak ada. Untuk kepentingan politik sehubungan dengan persekutuan atau teknik likuidasi bagi bank syariah, maka pada saat itu masalah kepailitan berbasis syariah di Indonesia diselesaikan dengan aturan baku Pasal 11. Aturan kepailitan berdasarkan syariah dalam aturan Indonesia hanya ada dalam Perma Nomor 2 Tahun 2008 tentang KHES dan anehnya kemudian beberapa artikel membicarakannya. Diantara pasal-pasal yang memuat pasal 11 dan PKPU mulai dari pasal 1 pasal 6, 7, 8, pasal 5 pasal 2, pasal 7 dan 8.) merupakan bentuk formalisasi syariat Islam yang sejati, hanya sebagai jalan untuk memenuhi syariat. kebutuhan dalam ruang sasaran pembahasan. NS. Sampai saat ini, kehadiran KHES oleh afiliasi tertentu belum ditanggapi, umumnya berpikir bahwa payung hukum belum berubah menjadi aturan untuk Pengadilan Tinggi. Ketiadaan aturan setingkat undang-undang yang mengatur pasal 11 yang bergantung pada akad syariah membuat kewenangan intervensi likuidasi dan kasus PKPU dalam asosiasi keuangan syariah justru masuk dalam ranah Busi mengingat, semua materiil yang termuat dalam Perma No. 2 Tahun 2008 tentang KHES juga mengandung hukum acara dan substansi khusus untuk melihat pasal 11 perkara yang bertumpu pada akad syariah dan jika signifikan payung hukumnya diperluas menjadi undang-undang. 
Hasil sah dari penanganan perkara subordinasi syariah pasal 11 oleh Pengadilan Niaga dengan cepat mempengaruhi pemanfaatan hukum materiil yang digunakan. Menurut pandangan utang syariah di Indonesia, ada kecenderungan untuk mengubah pengakuan komitmen syariah menjadi kewajiban konvensional. Hal ini menimbulkan kesan adanya ketegangan substansi hukum terkait uang syariah menjadi hukum moneter biasa.

Perubahan hakekat hubungan hukum secara khusus dapat dilihat dari bagian persyaratan pencatatan permintaan likuidasi dalam Pasal 2 Ayat (1) Undang-Undang Nomor 37 Tahun 2004 tentang Ayat 11 dan Penundaan Kewajiban Komitmen Bagian secara khusus. keberadaan bank dan pemegang obligasi. Setiap penyelidikan pasal 11 yang bertumpu pada syariah yang terjadi secara andal mengajukan upaya-upaya untuk dipaksakan untuk meningkatkan prasyarat para rentenir dan pemegang obligasi, meskipun perkumpulan tersebut (penghuni dan peminjam) tidak ada dalam setiap pembiayaan syariah, dalam syariah. pembiayaan hanya asosiasi afiliasi diketahui, khususnya satu pihak membantu yang lain. Lainnya, yang dibiayai untuk membantu orang-orang yang uang tunainya maupun sebaliknya, tidak memiliki alasan untuk mengeksploitasi pembiayaan Islam. Karena pendokumentasian kasus-kasus yang bergantung pada pengaturan syariah ke Pengadilan Bisnis, potensi untuk memadukan ide pembiayaan syariah nyata dengan pemikiran komitmen standar tidak diragukan lagi akan terjadi. ${ }^{14}$ Kedua, satu lagi akibat dari penanganan perkara pendirian usaha yang berkaitan dengan uang syariah oleh Pengadilan Niaga adalah akan terjadi sinkronisasi antara pengaturan dan alasan penyidikannya. Subbagian dan subbagian keuangan syariah dicakup oleh istilah bisnis syariah, misalnya murabahah, refleksi, mudharabah, qardh, hiwalah, ijarah, kafalah, dan sebagainya. Kasus-kasus diselesaikan dalam lingkungan yang sah yang benar-benar bertanggung jawab atas masalah-masalah yang berkaitan dengan nilai-nilai syariah Islam. Dalam hal diajukan pada struktur legitimasi yang tidak memiliki makna aturan syariah, yang akan muncul adalah tidak adanya kesepakatan antara akta kesepakatan dan motivasi di balik diskusi. Pemahaman diselesaikan di dalam struktur syariah, sedangkan penyelesaiannya dilakukan dalam lingkungan yang sah yang tidak menggunakan aturan dan norma syariah.

Untuk mengakhiri perjuangan baku antara UU no. 37 Tahun 2004 dan PERMA Nomor 2 Tahun 2008 harus dilakukan upaya sinkronisasi. Menurut penulis, kata pailit dan PKPU dalam Pasal 300 ayat 1 Undang-Undang Likuidasi Nomor 37 Tahun 2004 mempunyai arti umum atau mengandung arti umum yang mengacu pada standar dasar moneter yang berhadapan dengan Pasal 11 seperti perkumpulan perusahaan, perbankan umum, dll. hukum dibuat. Kesepakatan tentang kata likuidasi dan PKPU dalam landasan moneter bersama dalam pasal tersebut selama ini sebagian besar dirasakan pemikiran bahwa sifat umum mereka telah dibatasi oleh adanya lex specialis (spesialisasi) dalam penyajiannya. dari beberapa asosiasi terkait uang Islam. Penyajian asosiasi keuangan Islam mengurangi keberadaan lembaga keuangan adat yang memiliki substansi sendiri dari strategi otentik yang luar biasa dari tujuan diskusi menurut yang konvensional, di mana tujuan penyelidikan diselesaikan dengan mengandalkan norma-norma syariah. Di sini jelas ada PERMA nomor 2 Tahun 2008 yang dituangkan dalam pasal 7 ayat 2 sebagai lex specialis (aturan yang belum pernah terjadi sebelumnya) yang benar-benar menggantikan norma umum pasal 300 ayat $1 \mathrm{UU}$ Likuidasi dalam menyelesaikan olok-olok pasal 11 dan PKPU dalam Islam. organisasi moneter dengan memberikan kesanggupan kepada Pengadilan Tinggi untuk mengadilinya sesuai dengan perintah Undang-undang Nomor 3 Tahun 2006. Berdasarkan masalah yang menyertainya, dapatkah kedudukan PERMA lex master didasarkan pada standar yang sah? Pembuatnya sependapat dengan Jimly Asshidqie. ${ }^{15}$ yang mengandung Peraturan Induk (PERMA) sebagai peraturan yang tidak lazim sehingga tergantung pada peraturan lex master untuk mencemarkan badan pengatur yang bersifat generalis dan sesuai dengan yang direncanakan oleh pembuatnya selama belum ada peraturan perundangundangan yang mengatur pasal 11 dan PKPU dalam perkumpulan keuangan yang memanfaatkan syariah. prinsip., PERMA Nomor 2 Tahun 2008 sebagai pengisi 23 Jimly Asshidqie, Konstitusi dan Konstitusionalisme, hal. 278-279. 21 tidak sah untuk memilih kapasitas Pengadilan Agung dalam kasus likuidasi dan PKPU yang bergantung pada kontrak syariah.24 Pemberian kapasitas kepada Pengadilan Bisnis untuk melihat masalah kepailitan dan PKPU dalam asosiasi terkait uang yang menggunakan pedoman syariah adalah terlarang sikap dan bertentangan dengan amanat UUD 1945 yang menjamin kesempatan bagi setiap pengikutnya untuk mengamalkan ajarannya yang keras.25 Perubahan sesuai dengan hukum moneter syariah bagi umat Islam atau lembaga keuangan bahwa pemanfaatan prinsip syariah adalah hak dan peluang sentral untuk harus dipikirkan. Anehnya jika pembahasan pasal 11 dan PKPU dalam perkumpulan terkait uang syariah dipilih berdasarkan hukum moneter baku, bukan hukum keuangan syariah.

${ }^{14}$ Ghansam Anam, dkk, Problematika Aplikasi Ekonomi Syariah Dalam Rezim Hukum Kepailitan Di Indonesia, Jurnal Bina Mulia Hukum, Vol. 2, (2017), h. 70.

15 Dian Asriani Lubis, Kepailitan Menurut Ibnu Rusyd dan Perbandingannya Dengan Hukum Kepailitan di Indonesia, Jurnal Hukum Islam, Vol. XIII, No. 2, Nopember 2013,hlm.22. 


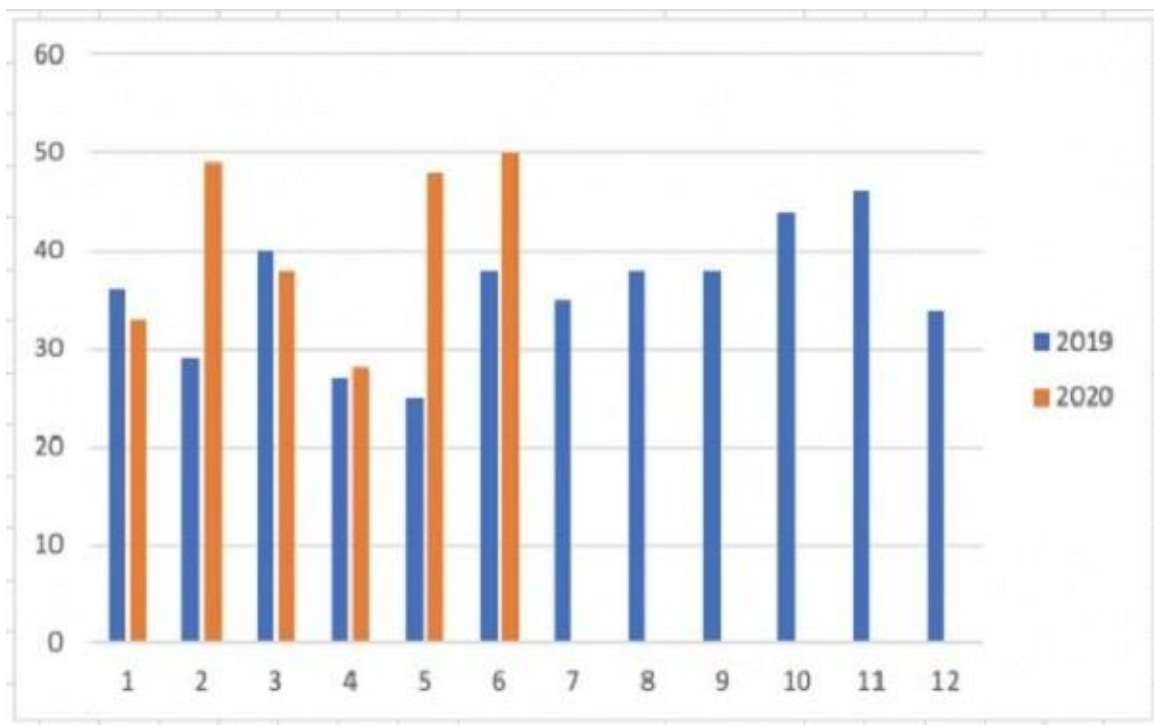

Persentase perkara kepailitan dan PKPU di lima Pengadilan Negeri periode Januari 2019-Juni 2020. Sumber: Riset HOL

Kuantitas kasus Pasal 11 dan PKPU akan terus berkembang selama pandemi. Contoh permohonan Pasal 11, khususnya PKPU, berkembang secara mendasar hingga saat ini. Menurutnya, kasus utang dan PKPU yang jauh jangkauannya karena debitur wanprestasi akibat Covid. Misalnya, tidak membuat tanggung jawab, misalnya, membayar komitmen karena keadaan keuangan asosiasi yang menurun. Kondisi ekonomi Indonesia mungkin akan berdampak besar karena Covid, meskipun penurunan Covid yang mempengaruhi dunia usaha, membuat para spesialis keuangan sulit untuk memenuhi tanggung jawab mereka dengan cara yang menyenangkan. Kompensasi mereka dipengaruhi kecuali jika asosiasi memiliki banyak spekulasi atau cadangan dana cadangan sehingga mereka dapat memenuhi tanggung jawab mereka. Praktis semua visioner bisnis akan kesulitan memenuhi tanggung jawabnya dalam kondisi pandemi Covid. Dengan selesainya aksi bisnis, cicilan juga akan berhenti. Hal ini membuat asosiasi lalai memenuhi kewajibannya untuk mengawasi tagihan tepat waktu.

\section{SIMPULAN}

Alasan terjadinya dualisme kekuasaan mediasi antara Pengadilan Niaga dan Pengadilan Tinggi dalam pasal 11 perkara dan PKPU dalam yayasan moneter syariah adalah karena tidak sinkronnya standar legitimasi yang termuat dalam Pasal 300 ayat 1 Undang-Undang Nomor 37 Tahun 2004 tentang Likuidasi dan PKPU serta Pasal 7 ayat 2 PERMA Nomor 2 Tahun 2008 tentang KHES. Ketidaksinkronan standar dalam kedua pedoman ini mendorong pengenalan pemahaman dualisme keterampilan arbitrase dalam kasus kepailitan dan PKPU dalam organisasi moneter Islam.

Perkara kepailitan dan PKPU yang didasarkan pada kontrak syariah sepenuhnya merupakan kemampuan Pengadilan Tinggi. Ini tergantung pada dua pendapat, khususnya profesional yang terlatih secara lex dan hipotesis kekuasaan. Kehadiran PERMA No. 2 Tahun 2008 menggantikan pengaturan Bab 11 UU yang standar hukumnya belum sampai pada substansi hukum keuangan syariah. Mengingat hipotesis kekuasaan, tidak salah lagi ada titik puncak ke posisi untuk memberikan penilaian. UU Kepailitan hanya terampil untuk menengahi kasus likuidasi dan PKPU di lembaga keuangan biasa, sementara UU Pengadilan Tinggi menengahi semua perdebatan moneter syariah mengingat kepailitan dan PKPU untuk organisasi moneter syariah.

Adanya kekosongan hukum atau klausul pelarian yang sah dalam set umum hukum di Indonesia di mana tidak ada pedoman yang jelas sehubungan dengan prosedur pailit atau metodologi untuk yayasan moneter Islam, sehingga perdebatan likuidasi yang bergantung pada kontrak syariah diselesaikan dengan kepailitan adat. pedoman. Pedoman likuidasi berdasarkan kontrak syariah dalam pedoman Indonesia hanya ada dalam PERMA Nomor 2 Tahun 2008 tentang KHES dan anehnya kemudian beberapa pasal menelitinya. Menurut penciptanya, kekurangan pedoman tingkat undang-undang yang mengatur likuidasi yang bergantung pada akad syariah adalah hal yang membuat otoritas menyelesaikan kasus kepailitan dan PKPU dalam organisasi moneter syariah masih berada di ranah Pengadilan Bisnis.

\section{DAFTAR PUSTAKA}

Adrian Sutedi ,Aspek Hukum Otoritas Jasa Keuangan. Jakarta : Raih Asa Sukses., 2014.

Ahmad Mujahidin,Prosedur Penyelesaian Sengketa Ekonomi Syariah di Indonesia, Jakarta: Ghalia Indonesia, 2010.

Any Nugroho, Hukum Perbankan Syariah. Yogyakarta:Aswaja Pressindo, 2015.

Daeng Naja, Akad bank Syariah, Pustaka. Yogyakarta:Yustisia, 2011.

Elyta Ras Gintin, Hukum Kepailitan : Teori Kepailitan. Jakarta : Sinar Grafika,2018. 
Jimly As-shiddiqie, Perihal Undang-Undang, Jakarta:LIPI,2004.

Jono, Hukum Kepailitan. Jakarta : Sinar Grafika, 2018.

Mardani, Hukum Ekonomi Syariah di Indonesia.Bandung:PT.Refika Aditama,2018.

Maria Farida Indrati S, Ilmu Perundang-Undang: Jenis, Fungsi, Materi Muatan. Yogyakarta: Kanisius, 2007.

Muh.Firdaus,dkk, Sistem dan Mekanisme Pengawasan Syariah.Jakarta : Renaisan, 2005.

Muhammad, Manajemen Bank Syariah.Yogyakarta : UPP AMP YKPN,2002.

M.Hadi Shubhan, Hukum Kepailitan, Prinsip, Norma, dan Praktik di Peradilan. Jakarta: Kencana Prenada Media Group,2012.

Munir Fuady, Hukum Pailit, Bandung : Citra Aditya Bhakti, 2002.

M. Natsir Asnawi, Hukum Acara Perdata, Teori, Praktik dan PERMAsalahannya di Peradilan Umum dan Peradilan Agama, Yogyakarta: UII Press, Cet. I, 2016

Soerjono Soekanto \& Sri Mamudji, Penelitian Hukum Normatif (Suatu Tinjauan Singkat), . Jakarta : Rajawali Pers,2001.

Sutiyoso Bambang, Penyelesaian Sengketa Bisnis : Solusi dan Antisipasi Bagi Peminat Bisnis Dalam Menghadapi Sengketa Kini dan Mendatang.Yogyakarta:Citra Media,2006.

Sutan Remy Sjahdeini, Hukum Kepailitan :Memahami Undang-Undang Nomor 37 Tahun 2004 Tentang Kepailitan. Jakarta: Pustaka Utama Grafiti,2009.

Serlika Aprita, Hukum Kepailitan dan Penundaan Kewajiban Pembayaran Utang:Perspektif Teori. Malang:Setara Press, 2018.

Sutan Remy Sjahdeini,. Sejarah, Asas, dan Teori Hukum Kepailitan: Memahami Undang-Undang No. 37 Tahun 2004 Tentang Kepailitan dan Penundaan Kewajiban Pembayaran. Jakarta: Kencana,2015.

Trisadini Prasastinah Usanti dan Nurwahjuni, Model Penyelesaian Kredit Bermasalah, (Surabaya: Revka Pertra Media, 2014

Victorianus M.H. Randa Puang, Penerapan Asas Pembuktian Sederhana dalam Penjatuhan Putusan Pailit, Cet. I. Bandung: Satu Nusa,2011.

\section{Jurnal}

Ashinta Sekar Bidari, Reky Nurviana. (2020). "Stimulus Ekonomi Sektor Perbankan Dalam Menghadapi Pandemi Coronavirus Disease 2019 Di Indonesia”, Jurnal Ilmu Hukum, Vol. 4 No. 1.

Dian Asriani Lubis. (2013). Kepailitan Menurut Ibnu Rusyd dan Perbandingannya Dengan Hukum Kepailitan di Indonesia, Jurnal Hukum Islam, Vol. XIII, No. 2.

Ifa Lathifa Fitriani. (2012). Kompilasi Hukum Ekonomi Syariah Dalam Pemaknaan Hukum Islam dan Sistem Hukum Positif di Indonesia, Jurnal Supremasi Hukum, Vol. 5 No. 1.

Yudha Indrapraja. (2014). Kegagalan Hukum di Indonesia Dalam Menciptakan Kepastian Hukum Terkait Sengketa Kepailitan Perbankan Syariah, Jurnal As-Syariah, Vol 16.

\section{Webinar}

Webinar"Menghadang Potensi Kepailitan Dalam Industri Keuangan Syariah, diselenggarkaan oleh Perkumpulan Konsultan Hukum Ekonomi dan Bisnis Syariah Indonesia (KoHEBSI) bekerjasama dengan TNC \& Friends dan Kantor Hukum Sidqi \&Sidqi Advocates, Jumat 10 Juli 2020. 